\title{
COUNSELING PSYCHOLOGY: A VIEW OF THE SCIENTIFIC PRODUCTION IN THE BRAZILIAN POSTGRADUATION
}

\author{
Fabio Scorsolini-Comin ${ }^{1}$, Manoel Antônio dos Santos ${ }^{2}$
}

\begin{abstract}
The study aims to outline the current view of the scientific production on counseling psychology from the analysis of theses and dissertations defended in the postgraduation program within the Brazilian context. The searches were carried out in the Digital Library of Theses and Dissertations at USP along with CAPES theses database. Thirteen dissertations were recovered and five theses were defended between 1989 and 2012. Master studies prevail in the existential-phenomenological approaches as well as person - centered with professional experience testimonials developed mainly in the services of higher public teaching institutions. It is recommended a greater researching variety, theoretical references also area interventions, thus strengthening the application of theoretical and technical assumptions in different contexts and populations.
\end{abstract}

Key words: counseling psychology, orientation, clinical psychology.

\section{INTRODUCTION}

The field of counseling psychology emerged in the 50's under strong influence of orientational practice which appeared in the United States along with other European countries. In Brazil, counseling psychology practice was one of the main areas to be incorporated to the Psychological teaching when the profession was regulated in 1962. Slowly it became acknowledged as a practice of the psychologist $^{1-2}$. Also known as a therapeutic counseling, it can be defined as an interpersonal relation, which from a dialogue as well as the genuine advisor presence aid the subject who looks for help by information supplying, the setting of a closing relation and careful listening at painful, doubtful and conflicting moments ${ }^{3}$.

Therefore, the history of counseling psychology in Brazil dates Psychology teaching history in the country. Such a field has been placed, since its regulamentation followed by graduation course opening, a key space and the Bachelor course in Psychology as the ones at USP - University of São Paulo and PUC - Pontifical Catholic University of São Paulo. Along the time, the marked North
American and European influence opened up space to the raise of studies conducted in the Brazilian context, together with researching institutes which proposed interventions not solely in the clinical field but also in groups and institutions.

Carl Rogers (1902-1987), prominent North American psychologist who has contributed to the Humanist Psychology development, is considered one of the major exponents in counseling psychology under the person-centered or clientcentered approach - ACP. Among the basic principles of the recommended technique by the approach are: non-direct focus based on the advisor's attitude attention, the establishment of an empathic relation, unconditional positive acceptance/consideration of the other focusing on helping set. ACP was one of the main references in the setting of counseling psychology field in Brazil, thus Rogers is a key author in the outlining of any area intervention ${ }^{1-4}$.

Due to the historical relevance, in our contemporary society, counseling psychology field has developed from stated experiences overall in the formation of new psychologists, in curricular trainings, basic trainings, community projects $^{5-7}$,

1 PhD in Psychology by University of São Paulo. Adjunct Professor at the Department of Psychology of Triângulo Mineiro Federal University.

2 Associate Professor in the Graduate Program in Psychology at Faculty of Philosophy, Sciences and Languages of Ribeirão Preto at University of São Paulo. Fellow of Brazilian Scientific and Technological Development Council (CNPq) Research Productivity. Corresponding author: scorsolini_usp@yahoo.com.br

Suggested citation: Scorsolini-Comin F, dos Santos MA. Counseling psychology: a view of the scientific production in the brazilian postgraduation. Journal of Human Growth and Development 2013; 23(3): 338-345

Manuscript submitted Mar 03 2013, accepted for publication Jul 202013. 
besides psychological care attendance. Inspired on counseling psychology assumptions, on call service offers a reception and a space for listening at the moment the subject needs help, hence the professional is available for that emergence psychological aid. Such a helping relation may be developed during one or more meetings depending on each needing case. The attendance may be developed in hospitals, schools and other institutions such as nurseries and police department ${ }^{8-9}$. For the sake of a better understanding of the challenges and potential of this area, however, it is fundamental to encourage scientific research, covering the different scenarios counseling has approached, whether in health ${ }^{10}$, education ${ }^{11-12}$ or within a general human development perspective ${ }^{13}$, keeping in mind the particularities of the interdisciplinary dialogue that characterizes contemporary psychological care. It is acknowledged that, in the graduate education context, much of this knowledge is not only produced, but also transmitted and disseminated to the scientific community. Hence, periodical revisions of scientific production are due.

From these considerations, this study aims to outline the current view of the scientific production over counseling psychology from the analysis of defended theses and dissertations in the postgraduation program within the Brazilian context.

\section{METHODS}

\section{Type of study}

This is a review study to find out in which works from studies are identified and selected under accuracy and scientific method, besides they were systematized as theses and dissertations which were approved as prerequisites for the granting of doctorate and master titles. Such qualified works are critically analyzed, so that it is possible to draw a produced study profile assessing the quality of contribution provided to the area of knowledge. We believe this review may contribute to a critical debate of the researching findings from the national context, along with point out gaps and perspectives to the development of future studies. The integrative review is considered a tool for a PBE - evidencebased practice, which enables the construction of systematized, grounded and even knowledge which may support a quality clinical practice ${ }^{14}$.

The guiding question adopted in the present study is: which is the scientific knowledge over the counseling psychology field produced in the postgraduation programs within the Brazilian context.

\section{Consulted Database}

With the objective of revising it was recovered developed studies in the national context from different areas of knowledge in the postgraduation programs; the search was carried out in the Digital Library of Theses and Dissertations at USP University of São Paulo \& the Bank of Theses Database of the Coordination of Improvement of Higher Education Personnel (CAPES). The first collection was created in 2001 to make it possible the knowledge produced by the master degree dissertations, doctorate and faculty theses defended at the University of São Paulo. The database targeted to allow international and Brazilian communities full access to the complete digital version of those materials. Digital Library is associated with a global initiative recognized by UNESCO - a Networked Digital Library of Theses and Dissertations (NDLTD), which guarantees greater reliability and comprehensiveness. Furthermore, it is associated with IBICT - Brazilian Institute of Information in Science and Technology of the Sciences and Technology Ministry, through the Brazilian Digital Library of Theses and Dissertations. CAPES Library aims to enable the access to information on theses and dissertations within postgraduation programs in the country, moreover it makes part of the Portal of Journals of CAPES/MEC. Considering the foregoing, the choice of such bases is justified by allowing to portrait accurately and systematically the scientific production related to the postgraduation system in the Brazilian context.

\section{Criteria for inclusion and exclusion of works}

In this revising study it was selected only master dissertations also doctorate and faculty theses. The Theses and Dissertations Database of USP recovers these modalities, besides the Theses Database of CAPES recovers the first two ones. It was not considered other types of studies usually recovered in literature reviews such as published journals, books, book chapters, course essays along with specialization essays. It was included studies related to the mentioned issue without language restriction, knowledge area, postgraduation program, researching line or publishing date. It was discarded the ones either not related to or not close to the counseling psychology theme irrespective to the knowledge area in which they were produced.

\section{Procedure}

The survey phase of theses and dissertations were held in July 2013. It was used the 'psychological counseling' descriptor in Portuguese and English which should be present either in the title and / or in the work abstract, moreover the combination of the terms 'counseling' and 'psychological'.

Firstly, it was carried out a detailed reading from the term excluding the works which did not suit the outlined criteria. After a first selection from the abstracts, the theses and dissertations were recovered and read in full. Then, due to a greater or lesser proximity to the theme, another selection was 
carried out limiting the review to the studies directly related to psychological counseling, ruling out works which only mentioned this field or some techniques. It was excluded studies which both analyzed counseling psychology and the ones which applied their techniques on some disease or intervention.

Consequently it was taken into account for debating, the works recovered in the last selection phase. The corpus was organized in categories according to content similarity, work type, which are theses or dissertation, also knowledge subarea which made it easier to visualize characteristics, limits and potentialities of the recovered scientific knowledge.

\section{RESULTS}

It was located 162 studies in the CAPES Theses Database and eight in the Theses Digital
Library at USP, from the keywords 'psychological counseling', and the combination of the keywords 'counseling' and 'psychological'. From the inclusion and exclusion criteria the survey corpus was comprised of 18 (eighteen) works, 13 (thirteen) of which were master dissertations and 5 (five) of them were doctorate theses (Table 1 ). The reduction of registry number is largely due to the fact that the term 'psychological counseling' does not mean an area or field of Psychology application, but as a general expression to name an aiding relation or psychological attendance. The studies which do not specifically refer to counseling psychology area were not selected.

Eighteen full recovered and analyzed studies were characterized in Table 2 in terms of title, authorship, year of presentation to the department, program, besides teaching institution at which they were developed.

Table 1: Intellectual contribution listed in the Bank of Theses Database of the Coordination of Improvement of Higher Education Personnel (CAPES) and Digital Library of Theses and Dissertations at USP - University of São Paulo, Brazil, 2013

$\begin{array}{lcc}\text { Keywords } & \begin{array}{c}\text { CAPES } \\ \text { Theses Database }\end{array} & \begin{array}{c}\text { Digital Library of Theses } \\ \text { Dissertations at USP }\end{array} \\ \text { "Counseling Psychology" } & 22 & 8 \\ \text { "Counseling" and "Psychology" } & 140 & 8 \\ \text { Total of found records } & 162 & 8 \\ \text { Selected by title } & 30 & 6 \\ \text { Recovered by abstract } & 19 & 5 \\ \text { Full recovery 1913 } & 13 & 5 \\ \text { Total } & 18 \text { (13 Dissertations } \\ & \text { and 5 Theses) }\end{array}$

Table 2: Features of recovered theses and dissertations by title, authorship, institution at which the work was defended, Brazilian postgraduation program and year of publishing $(n=18)$. Brazil, 2013

\begin{tabular}{|c|c|c|c|c|c|c|}
\hline $\mathbf{n}$ & Title & Author & Type & Institution & Program & Year \\
\hline 1 & $\begin{array}{l}\text { I-supervision: In scene an action seeking for } \\
\text { meaning }\end{array}$ & Morato & Doctorate & $\begin{array}{l}\text { University of } \\
\text { São Paulo }\end{array}$ & $\begin{array}{l}\text { School Psychology and } \\
\text { Human Development }\end{array}$ & 1989 \\
\hline 2 & $\begin{array}{l}\text { Training students in } \\
\text { Psychology: a possibility for educators }\end{array}$ & Eisenlohr & Master & $\begin{array}{l}\text { University of } \\
\text { São Paulo }\end{array}$ & $\begin{array}{l}\text { School Psychology and } \\
\text { Human Development }\end{array}$ & 1997 \\
\hline 3 & $\begin{array}{l}\text { Contributions of Family Structural Therapy and } \\
\text { Narrative Therapy for pastoral counseling of low } \\
\text { resources, multi problematic families }\end{array}$ & Streck & Doctorate & $\begin{array}{l}\text { School of } \\
\text { Higher } \\
\text { Theology }\end{array}$ & Pastoral Theology & 1998 \\
\hline 4 & $\begin{array}{l}\text { Affective relationship between teacher and } \\
\text { student: reflections on science learning }\end{array}$ & Cardozo & Master & \multirow{2}{*}{$\begin{array}{l}\text { Federal } \\
\text { University of } \\
\text { Mato Grosso } \\
\text { University of } \\
\text { São Marcos }\end{array}$} & Education & 2000 \\
\hline 5 & $\begin{array}{l}\text { Training supervision in psychological counseling: } \\
\text { considerations from a statement over an } \\
\text { experienced process of a group of trainees }\end{array}$ & Telles & Master & & Psychology & 2000 \\
\hline 6 & $\begin{array}{l}\text { Storytelling and expressing oneself: relevant } \\
\text { learning and psychological attendance opening } \\
\text { possibilities for a clinics }\end{array}$ & Chalom & Master & $\begin{array}{l}\text { University of } \\
\text { São Paulo }\end{array}$ & $\begin{array}{l}\text { School Psychology and } \\
\text { Human Development }\end{array}$ & 2001 \\
\hline 7 & $\begin{array}{l}\text { Re-meaning clinical psychology in a burned child } \\
\text { assistance: an experience into question }\end{array}$ & Carvalheira & Master & \multirow{2}{*}{$\begin{array}{l}\text { Catholic } \\
\text { University of } \\
\text { Pernambuco } \\
\text { Catholic } \\
\text { University of } \\
\text { São Paulo }\end{array}$} & Clinical Psychology & 2003 \\
\hline 8 & $\begin{array}{l}\text { Similarities and differences between psychological } \\
\text { attendance and religious attendance: the last } \\
\text { steps of a man }\end{array}$ & Larrabure & Master & & Clinical Psychology & 2003 \\
\hline 9 & $\begin{array}{l}\text { Being a clinical educator: a phenomenological and } \\
\text { existential reading of some themes in the practice } \\
\text { of health and education professionals }\end{array}$ & Almeida & Doctorate & $\begin{array}{l}\text { University of } \\
\text { São Paulo }\end{array}$ & $\begin{array}{l}\text { School Psychology and } \\
\text { Human Development }\end{array}$ & 2005 \\
\hline 10 & $\begin{array}{l}\text { Between meaningful learning and interventive } \\
\text { methodology: clinical praxis of an university lab } \\
\text { as counseling psychology }\end{array}$ & Nunes & Master & $\begin{array}{l}\text { University of } \\
\text { São Paulo }\end{array}$ & $\begin{array}{l}\text { School Psychology and } \\
\text { Human Development }\end{array}$ & 2006 \\
\hline 11 & $\begin{array}{l}\text { Clinics, experience and meaning: narratives of } \\
\text { physicians }\end{array}$ & Oliveira & Master & $\begin{array}{l}\text { University of } \\
\text { São Paulo }\end{array}$ & $\begin{array}{l}\text { School Psychology and } \\
\text { Human Development }\end{array}$ & 2006 \\
\hline
\end{tabular}




\begin{tabular}{|c|c|c|c|c|c|c|}
\hline $\mathbf{n}$ & Title & Author & Type & Institution & Program & Year \\
\hline 12 & $\begin{array}{l}\text { The internal young offender by the Statute of Child } \\
\text { and Youngster and pastoral psychological counseling }\end{array}$ & Nilsson & Master & $\begin{array}{l}\text { School of } \\
\text { Higher }\end{array}$ & Pastoral Theology & 2007 \\
\hline 13 & $\begin{array}{l}\text { Interface between counseling psychology and spiritual } \\
\text { counseling }\end{array}$ & Pereira & Master & Catholic & Clinical Psychology & 2009 \\
\hline 14 & $\begin{array}{l}\text { Journey of life and sexuality: a study from } \\
\text { testimonials of men and women attended at the } \\
\text { counseling psychology attendance at IPUSP }\end{array}$ & Toniette & Doctorate & $\begin{array}{l}\text { University of } \\
\text { São Paulo }\end{array}$ & $\begin{array}{l}\text { School Psychology and } \\
\text { Human Development }\end{array}$ & 2009 \\
\hline 15 & $\begin{array}{l}\text { Contribution of counseling psychology for a spiritual - } \\
\text { driven practice }\end{array}$ & Pisaneschi & Master & $\begin{array}{l}\text { Catholic } \\
\text { University of } \\
\text { São Paulo }\end{array}$ & Clinical Psychology & 2009 \\
\hline 16 & $\begin{array}{l}\text { Supervision of supervision: wide phenomenological } \\
\text { view in mapping clinical practices within institutional } \\
\text { and communitarian contexts }\end{array}$ & Braga & Doctorate & $\begin{array}{l}\text { University of } \\
\text { São Paulo }\end{array}$ & $\begin{array}{l}\text { School Psychology and } \\
\text { Human Development }\end{array}$ & 2010 \\
\hline 17 & $\begin{array}{l}\text { Genetic Counseling: Analysis and contributions from } \\
\text { counseling psychology model }\end{array}$ & Hannum & Master & $\begin{array}{l}\text { Catholic } \\
\text { University of } \\
\text { Goiás }\end{array}$ & Psychology & 2011 \\
\hline 18 & $\begin{array}{l}\text { Sacramental confession in the Catholic Church and } \\
\text { psychological counseling }\end{array}$ & Mercês & Master & $\begin{array}{l}\text { Catholic } \\
\text { University of } \\
\text { São Paulo }\end{array}$ & Clinical Psychology & 2012 \\
\hline
\end{tabular}

Most found studies were developed together with the Postgraduation Program in the School Psychology and Human Development of the University of São Paulo $(n=8)$ followed by the studies of the Postgraduation Program in Clinical Psychology of Pontifical Catholic University of São Paulo $(n=5)$. It was found two records in the Theology area and just one in Education. Only two studies were developed in postgraduation programs in the Center-West and Northeast regions; there is a strong concentration of work from São Paulo state, mainly from Pontifical Catholic University of São Paulo (PUC) also IPESP - Institute of Psychology of USP. Most of those works were not released in article format or books what it was noted from the consultation with the curriculum of postgraduates which are available in the Lattes Platform. Not serving these materials through high impact scientific sources ultimately weakens scientific production on counseling psychology in the Brazilian context, making knowledge in the area confined to researches over developed practices at and by universities which hold Psychology courses.

It was not found more than a study under the same author, therefore considering the analyzed sample, it was not identified researchers who developed both master and doctorate degrees in psychological counseling. The dominance of research from IPUSP may be explained by the presence of SAP-IPUSP ${ }^{5}$ - Counseling Psychology Attendance linked to the Department of Learning Psychology of Development and Personality. The Department was founded in 1969 to the purpose of graduating students in Psychology, developing researches in psychological counseling, also offering free attendance to the ones who look for psychological help. SAP also keeps a psychological attendance service, mentioned in some studies recovered in this current review. Besides SAP, it is based at the same institution the Laboratory for Studies \& Practice in Existential Phenomenological Psychology (LEFE) which renders psychological services to institutions in the health and educational areas $^{15}$.
Concerning publishing dates of the revised studies, since there was no a priori constraint in relation to this criterion, the first recovered record was the thesis in 1989, defended by the researcher Henriette Tognetti Penha Morato, who later on would take the leadership of the Lab, including she had oriented most of the studies which made part of the corpus of this review. The mentioned author is considered one of the greatest references in the Brazilian psychological counseling, mainly in the existential phenomenological approach.

The latest study is from 2012. Most studies $(n=12)$ were produced in the last ten years what reveals the novelty of such researches. Although, such a remark shall be analyzed carefully because the applied database does not permit the recovery of the entire postgraduation production in the country, otherwise the ones registered in digital libraries of CAPES and USP.

Concerning the psychological approaches used in the studies, according to Chart 3 , it is noted the dominance of existential phenomenological $(n=8)$ along with ACP $(n=6)$, the last one created and disseminated by Carl Rogers, considered one of the exponents of counseling psychology as previously referred to. There were references to other approaches as to psychoanalysis $(n=1)$, Jung psychoanalysis $(n=1)$ and narrative therapy $(n=1)$. Just one study did not mention its applied approach, the dissertation from the educational field. Clear reference to applied psychological approach reveals one key charac-teristics of psychological counseling, which is the well - defined epistemological position when setting a helping relation. Thus, when they propose interventions and listening practices, they are built from concepts from the man, the world, the clinics, scientific knowledge moreover interpersonal relationship. The existential-phenomenological approach is person-centered, also known as humanist, they are strands in the studies of SAPIPUSP ${ }^{5,15}$, reason for which they are frequently mentioned. So, in the counseling psychology field, 
it is noted the relevance of such a service not only in the psychologist formation, but also of faculty, researchers in the postgraduation level, what highlights its contribution to the tripod teaching, research and extension so proclaimed in the teaching public institutions.

Table 3: Starting questions (General goals) and psychological approaches applied in theses and dissertations on Counseling Psychology $(n=18)$. Brazil, 2013

\begin{tabular}{|c|c|c|}
\hline $\mathbf{n}$ & General goals & $\begin{array}{l}\text { Theoretical } \\
\text { approach }\end{array}$ \\
\hline 1 & $\begin{array}{l}\text { To investigate supervising activity development of an advisor of Counseling psychology Attendance of IPUSP } \\
\text { to understand the meaning of his/her work with students in the } 5^{\text {th }} \text { year of Psychology }\end{array}$ & $\begin{array}{l}\text { Person-centered } \\
\text { approach }\end{array}$ \\
\hline 2 & $\begin{array}{l}\text { To understand the formation of psychology students in the person-centered theoretical practicing approach in } \\
\text { the person of Carl Rogers and followers, by which it is based the Counseling psychology Attendance of Psychology } \\
\text { Institute of USP }\end{array}$ & $\begin{array}{l}\text { Person-centered } \\
\text { approach }\end{array}$ \\
\hline 3 & $\begin{array}{l}\text { To help to meet a more suitable way to perform pastoral counseling toward low resource and multi problematic } \\
\text { families through multi systemic attendance at the Christian community context }\end{array}$ & $\begin{array}{l}\text { Narrative Therapy } \\
\text { and Family } \\
\text { Structural Therapy }\end{array}$ \\
\hline 4 & $\begin{array}{l}\text { To define positive and negative consequences in the teacher-student relationship in the science learning in } \\
\text { the } 5^{\text {th }} \text { and } 7^{\text {th }} \text { years }\end{array}$ & - \\
\hline 5 & $\begin{array}{l}\text { To understand the development of the trainee - student during training supervisions in Counseling psychology } \\
\text { at a course of Psychologists }\end{array}$ & Psychoanalysis \\
\hline 6 & $\begin{array}{l}\text { To debate the type of help psychology and psychologist can offer currently; debate the modern man and the } \\
\text { importance of a view which includes the subject as a participant being in the world learning process }\end{array}$ & $\begin{array}{l}\text { Jung } \\
\text { Phenomenological } \\
\text { Approaches }\end{array}$ \\
\hline 7 & $\begin{array}{l}\text { To debate established clinical assisting models available at psychological demands of burned hospitalized } \\
\text { children }\end{array}$ & $\begin{array}{l}\text { Existential- } \\
\text { Phenomenological }\end{array}$ \\
\hline 8 & To compare psychological attendance and religious attendance based on the film "The last steps of a man" & $\begin{array}{l}\text { Person-centered } \\
\text { approach }\end{array}$ \\
\hline 9 & $\begin{array}{l}\text { To present an existential - phenomenological reading in the health education professional practice; to analyze } \\
\text { the Psychological Attendance, a modality of counseling psychology }\end{array}$ & $\begin{array}{l}\text { Existential- } \\
\text { Phenomenological }\end{array}$ \\
\hline 10 & $\begin{array}{l}\text { To investigate how a university lab has built and performed Clinical Psychological Attention Projects in institution, } \\
\text { in the Counseling psychology field }\end{array}$ & $\begin{array}{l}\text { Existential- } \\
\text { Phenomenological } \\
\text { and Meaningful } \\
\text { Learning }\end{array}$ \\
\hline 11 & To understand trainees' experience at LEFE/USP concerning Psychological Attendance practice & $\begin{array}{l}\text { Existential- } \\
\text { Phenomenological }\end{array}$ \\
\hline 12 & $\begin{array}{l}\text { To develop a manual for Pastoral Counseling psychology to Internal Young Offenders based on the Statute of } \\
\text { Child and Youngster }\end{array}$ & $\begin{array}{l}\text { Pastoral } \\
\text { Counseling }\end{array}$ \\
\hline 13 & $\begin{array}{l}\text { To understand the similarities and differences between counseling psychology understood in a humanistic } \\
\text { perspective and spiritual counseling developed in the catholic religion }\end{array}$ & Phenomenology \\
\hline 14 & $\begin{array}{l}\text { To get to know meanings and senses in the sexual social building and of genders from emotional \& social } \\
\text { experience of men and women who seek attendance at Psychological Attendance of Counseling psychology(SAP- } \\
\text { IPUSP) revealing affective-sexual complaints }\end{array}$ & $\begin{array}{l}\text { Existencial- } \\
\text { Phenomenological }\end{array}$ \\
\hline 15 & $\begin{array}{l}\text { To research possible contributions on counseling psychology for the spiritual - driven practice in the Catholic } \\
\text { religion perspective in the light of the interdisciplinary dialogue }\end{array}$ & $\begin{array}{l}\text { Person-centered } \\
\text { Approach }\end{array}$ \\
\hline 16 & $\begin{array}{l}\text { To investigate clinical practice of the advisor's supervision, debating space between clinical advisors of different } \\
\text { projects of psychological care at institutions and communities }\end{array}$ & $\begin{array}{l}\text { Existential- } \\
\text { Phenomenological }\end{array}$ \\
\hline 17 & $\begin{array}{l}\text { To use the counseling psychology model to carry out genetic counseling as an alternative way to perform } \\
\text { interface between areas, assessing possible contributions of Psychology }\end{array}$ & $\begin{array}{l}\text { Person-centered } \\
\text { Approach }\end{array}$ \\
\hline 18 & $\begin{array}{l}\text { To think over spiritual counseling and sacramental confession at the perspective of counseling psychology } \\
\text { developed in the person-centered approach }\end{array}$ & $\begin{array}{l}\text { Person-centered } \\
\text { Approach }\end{array}$ \\
\hline
\end{tabular}

Concerning the target of produced studies, there is predominance of the survey of certain professional experience linked to the counseling psychology field developed in universities. In this keynotes, there are testimonials of training supervisors in psychological counseling, as well as of trainees of Psychology ${ }^{16-18}$. Such studies search for the understanding of meanings assigned by students and their supervisors in the listening and helping process developed in the counseling psychology field moreover psychological attendance ${ }^{19}$. To that purpose they refer to the existential phenomenological approach, mainly according to the Heidegger ${ }^{20}$ assumptions about the human being, also his search for self - knowledge. It is important to highlight the developed studies tried to map similarities and differences between counseling psychology and religious counseling in the catholic religious perspective ${ }^{21-22}$. The priests are understood as advisors who can appropriate counseling psychology techniques like mirroring and hosting toward establishing an aiding relation with the seekers who look for them. There are studies that mention spiritual counseling which are models directly influenced by psychological counseling, their knowledge and techniques ${ }^{22}$. In 
another type of counseling called genetic, the author 23 maps parallel between two forms of counseling coming to the conclusion that they are distinct approaches to the extent that genetic counseling involves greater directivity in a view of the human being more related to the body, illness and immediate help, therefore many steps claimed by counseling psychology end up not being applied in the service routine of specialized health.

Table 4 summarizes key results and conclusions found in the studies which make part of the corpus analysis. Experience testimonials of trainees and supervisors evidence the psychological formation process emphasizing the supervising spaces of clinical activities bonded with counseling. The assumption of the advisor's identity would be enabled by learning during attendance, including supervisions which would explore the advisor's place in the therapeutic relation, its challenges also potentialities in helping. The advisor shall keep a willingness attitude to reflect constantly over their own experiences, unveiling limits and possibilities to ensure they can operate properly ${ }^{18,19}$. The same may be said in relation to the advisor who shall put into appreciation the supervising practice contributing to the training of other professionals. It is raised how students' testimonials under the training process were maturing from attendance and supervisions in the same way supervisors could recognize specific characteristics of the supervisor's clinical training.

Table 4: Main obtained results and conclusions from theses and dissertations on Counseling Psychology ( $n$ =18). Brazil, 2013

\footnotetext{
n Main results / conclusions

1 Lived experiences by the supervisor allowed meaning and purpose of I-supervisor which is an experimental learning process

2 It was highlighted particularly, students' experience of last semester of Psychology graduation, considering a special period of training, in which crisis experiences are emphasized which were provoked by the passage of students to professional phase

3 For pastoral counseling to low resource multi problematic families, the Church may form a network of work to those families enabling them to benefits within the interdisciplinary approach

4 The teacher-student relationship comprises one of the accounting factors to the student's cognitive expansion, assuring emotional stability in the teacher's work. In turn, when it is negative, teacher-student relationship contributes to student's intellectual hindrance provoking the teacher's emotional exhaustion, impoverishing him affectively

5 It was noted trainees' development linked to their changes in attitudes along with point of views during the supervisions. Trainees have noticed the importance of personal therapeutic work in parallel with supervision. They have also been aware of the interference of transference and counter - transference aspects related to the client, supervisor and friends which change some fears and idealizations concerning the supervisor's role and psychotherapist's role, replacing initial fantasies for experienced based real perceptions

6 Graphical resources for interviewees' experience understanding as well as story narrations opened up reflections about the possibility of making out experiences as feedstock to be worked out by the psychologist in a variety of ways in different contexts

$7 \quad$ Psychological action in burning treatments is placed in the theoretical -practical field of Counseling Psychology as psychological clinical and educational practice which unfolds in an interdisciplinary dimension of clinical social action. It was found communication details among the psychologist, the child also her mother, understood as tools / appliances which could favor psychological intervention

8 Bring light to a human being who seeks aid, showing him/her the best within, leading him/her to a maturing state so that he she feels comfortable to take action in life; it does not concern only the psychologist but everyone who deals with the human being. Although, there are visible similarities mainly in the technical area, the convictions and religious values in helping moving away from the psychologist work

9 It explains the facets of plurality and singularity of the ' $I$ ', mentioning impropriety, property, promptitude, anguish, care, sense, finitude, and awareness. It proposes a perspective of integration between clinics and education. The dimension of the clinical being as educator under the condition of being affected, understand and talk. Importance of anguish, interpretation, sense and language

10 Subject's listening possibility at the institution getting away from an institutional perspective. Understanding of a subjective way closely linked to social, cultural and institutional aspects, besides temporality as occurrence. Mapping attitudes as a way for clinical suitable actions engineered in the institutional contexts

11 It was presented 'on call' shift, revealing some peculiarities which characterize this practice modality as another option to understand the clinical Psychology

12 It is raised ideas for enhancing counseling through love, dedication and vocation. There is a strong legal focus of religious assistance as constitutional principle, ruling of Statute of Child and Youngsters also the way to carry it out by Pastoral Counseling psychology

13 Interface between two aiding modalities - counseling psychology in a humanist view and spiritual counseling of a catholic inspiration - can be considered as an interdisciplinary area of neighbor disciplines, since there is a crossing space where there inspiration - can be considered as an interdisciplinary area of neigh
are concepts and techniques common to both counseling types

14 Testimonials reveal tension between idealized affective sexual experience and the lived affective sexual experience, intensifying anguish and suffering events. The psychological model offered by the Psychological Attendance prioritizes the value of lived experiences from the meeting, care, attention, getting away from a normative focus of psychotherapeutic attendance

15 Spiritual directorate is a spiritual aid relationship, the light of faith in Jesus Christ, between the spiritual director and the oriented person by which the first helps the second to peer into his/her life experiences, the signals of God to better his/her relationship within oneself, with others and with God. There are appropriation of attitudes and concepts of the counseling psychology in the spiritual directive practice

16 Concerning the counseling psychology place from the existential phenomenology, psychological attention is understood as the possibility of designating the relevant praxis, encompassing the look on experience while a way to live on the world. The possibility of designating the relevant praxis, encompassing the look on experience while a way to live on the world. The
supervision of the supervision is understood as a wide angle in which interpenetrate five dimensions: Mapping-investigative, supervision of the supervision is understood as a wide
theoretical-practical, pedagogical, political - ethical

17 There is a dissonance between the theoretical proposition supported by the advisor and the practiced action during the genetic counseling. The safeguarding of the non -directive principle and the affective factors like anguish and identification along with the psychic defense as rationalization restrained the diagnostic communication compromising the clarity of the vital context of the consultant

18 Spiritual counseling and confession are helping relations which narrow the advisor and client relation proposed by the person centered approach for psychological counseling. The developed knowledge in the counseling psychology area can raise
} 
In the studies targeted to compare counseling psychology techniques with spiritual counseling ${ }^{21-22}$ and genetic counseling 23 , for example, it was clear practicing and the advisor's image. Although, counseling processes may be approached since they involve interpersonal helping relation from a conflict or situation brought by the client; counseling techniques show themselves to be distant inasmuch one tends to focus on information delivery as well as more directive orientation and guidance based on clinical evidences ${ }^{23}$, and the other has as its baseline the advisor's mystical experience and belief ${ }^{21}$. Thus, though we can state they are counseling processes, special characteristics may be marked and reflected so counseling psychology does not lack its identity amid the desired interdisciplinary.

As a recurrent feature in all mentioned researches, it is noted the critical reflection around the advisor, the formation, preparation and supervision what contribute to characterize the counseling psychology area along with outline its boundaries ${ }^{3,6-7}$. Highlighting the advisor's training in those productions allow stressing one of the main counseling psychology assumptions regularly observed by Brazilian researchers in their interventions, which are the attitude and behavior of whom offer help.

From outlining the Brazilian postgraduation production in the counseling psychology field, some consideration shall be pointed out. Firstly, master degree studies developed in the existential phenomenological approaches and person-centered prevail with professional experience testimonials developed above all in attendance services located at teaching public institutions. Thereby, counseling psychology seems too much linked to the clinical area with few references to other application environments like companies, schools, nursings, political station, forums, hospitals, outpatients clinics, basic health care units, psychosocial attendance centers among other services and institutions.

The linkage to the clinics also seems associated to the emphasis on developing clients

\section{REFERENCES}

1. Morato HTP. Aconselhamento psicológico: uma passagem para a transdisciplinaridade. In: Morato HTP, org. Aconselhamento psicológico centrado na pessoa: novos desafios. São Paulo: Casa do Psicólogo; 1999. p. 61-90.

2. Schmidt MLS. Aconselhamento psicológico: questões introdutórias. In: Rosenberg RL, org. Aconselhamento psicológico centrado na pessoa. São Paulo: EPU; 2001. p. 14-23.

3. Forghieri YC. O aconselhamento terapêutico na atualidade. Rev. Abordagem Gestalt., 2007; 13(1): 125-33.

4. Schmidt MLS. Clínica-escola, escola da clínica? Boletim de Psicologia da Sociedade de Psicologia de São Paulo, 1992; 42 (96/97): 99-103. individually with few records of group counseling, of parents, teachers, team work or couples, in a close relationship with the traditional training of the clinical psychologist centered in the relation clientpatient. The closeness in the counseling psychology in the educational field, for instance, aims not only to promote a reading of the helping relationship in non-clinical contexts, but also enables human development in situations in which counseling techniques reveal to be suitable, favoring to trigger changes. Production of new knowkedge shall pay attention to such a move.

Thinking about the diversity which permeates the current field of counseling psychology it is proposed that other researches are held approaching their technical help with other helping environments and receive people in a state of anguish also emotional distress. Moreover, a diversity of approaches can contribute to map other relevant aspects in the process under the focus of problem - solution or more appreciative approaches which seek the strengthening of people's adaptability and resilient abilities as proposed by the Positive Psychology. Though, such more contemporary approaches are also influenced by authors like Rogers, as it is the case of Positive Psychology, there should be opened spaces for new researching and interventions that can be developed and assessed in a variety of contexts under a growing commitment with postgraduation development.

It is, thus, evident that there is a specific profile and can be considered to some extent unambiguous of the studies in counseling psychology in the national context, maybe by the fact that the scientific production in the area is still limit to only a few researching groups. Therefore, in addition to the developed studies by these pioneering centers in Brazil, it is important to encourage other existing studying and researching centers to convey their productions contributing to the empowerment of counseling psychology along postgraduation programs.

5. Nunes AP, Morato HTP. A práxis clínica de um laboratório universitário como aconselhamento psicológico. Boletim de Psicol. 2008; 58 (128): 73-84.

6. Hutz-Midgett A, Hutz CS. Counseling in Brazil: past, present, and future. J Counseling \& Develop. 2012; 90(2): 238-42. doi: http:// dx.doi.org/10.1111/j.1556-6676.2012. 00030.x

7. Sexton TL. The relevance of counseling outcome research: current trends and practical implications. J Counseling \& Develop. 1996; 74(1): 590-600. doi: http://dx.doi.org/ 10.1002/j.1556-6676.1996.tb02298.x

8. Yehia GY. Interlocuções entre o plantão psicológico e o psicodiagnóstico colaborativo. Estudos de Psicol. 2004; 21(1): 65-72. doi: 
http://dx.doi.org/10.1590/S0103166X2004000100006

9. Campos APS, Cury VE. Atenção psicológica clínica: encontros terapêuticos com crianças em uma creche. Paidéia (Ribeirão Preto). 2009; 19(42): 115-21. doi: http://dx.doi.org/ 10.1590/S0103-863X2009000100014

10. Atrash K, Carpentier R. The evolving role of public health in the delivery of health care. Rev Bras Cresc Desenvolv Hum. 2012; 22(3): 396-9.

11. Leite RV, Mahfoud M. Cuidar da educação, da cultura e de si: horizontes de uma experiência de resgate da cultura popular na escola. Rev Bras Cres Desenvolv Hum. 2007; 17(2): 74-86.

12. Urofsky RI. The council for accreditation of counseling and related educational programs: promoting quality in counselor education. J Counseling \& Develop. 2013; 91(1): 6-14. doi: http: //dx.doi.org/10.1002/j.15566676.2013.00065.x

13. Scorsolini-Comin F, Santos MA. Bakhtin e os processos de desenvolvimento humano: um diálogo de, no mínimo, duas vozes. Rev Bras Cresc Desenvol Hum. 2010; 20(3): 805-17.

14. Paranhos VD, Pina JC, Mello DF. Integrated management of childhood illness with the focus on caregivers: an integrative literature review. Rev. Latino-Am. Enfermagem. 2011; 19(1): 203-11. doi: http://dx.doi.org/10.1590/S010411692011000100027

15. Nunes AP, Morato HTP. Entre aprendizagem significativa e metodologia interventiva: práxis clínica de um laboratório universitário como Aconselhamento Psicológico. In: Morato HTP, Barreto CABT, Nunes AP, orgs. Aconselhamento psicológico numa perspectiva fenomenológica existencial. Rio de Janeiro: Guanabara Koogan; 2009. p. 89-100.

16. Eisenlohr MGV. Formação de alunos em Psicologia: uma possibilidade para educadores
[Master's Thesis]. São Paulo: Instituto de Psicologia da Universidade de São Paulo; 1997. p. 56-88.

17. Telles SRA. Supervisão de estágio em aconselhamento psicológico: considerações sobre o relato de um processo experienciado por um grupo de estagiários [Master's Thesis]. São Paulo: Universidade São Marcos; 2000. p. 22-45.

18. Nunes AP. Entre aprendizagem significativa e metodologia interventiva: a práxis clínica de um laboratório universitário como aconselhamento psicológico [Master's Thesis]. São Paulo: Instituto de Psicologia da Universidade de São Paulo; 2006. p. 91-205.

19. Braga TBM, Mosquera SM, Morato HTP. Cartografia clínica em plantão psicológico: investigação interventiva num projeto de atenção psicológica em distrito policial. Temas em Psicol. 2012; 20(2): 555-69. doi: http:// dx.doi.org/10.9788/TP2012.2-20

20. Almeida FM. Ser clínico como educador: uma leitura fenomenológica existencial de algumas temáticas na prática de profissionais de saúde e educação [Doctoral Dissertation]. São Paulo: Instituto de Psicologia da Universidade de São Paulo; 2005. p. 91-177.

21. Mercês GS. A confissão sacramental na Igreja Católica e o aconselhamento psicológico [Master's Thesis]. São Paulo: Pontifícia Universidade Católica de São Paulo; 2012. p. 30-56.

22. Pisaneschi V. Contribuições do aconselhamento psicológico para a prática da direção espiritual [Master's Thesis]. São Paulo: Pontifícia Universidade Católica de São Paulo; 2009. p. 69-85.

23. Hannum JSS. Aconselhamento genético: análise e contribuições a partir do modelo do aconselhamento psicológico [Master's Thesis]. Goiânia: Pontifícia Universidade Católica de Goiás; 2011. p. 52-63. 